\title{
Reflecting on PASUC Heritage Initiatives through Time, Positionality, and Place
}

\author{
Scott Hutson ${ }^{1, *}$, Céline Lamb ${ }^{1}$, Daniel Vallejo-Cáliz ${ }^{1}$ and Jacob Welch ${ }^{2}$ \\ 1 Department of Anthropology, University of Kentucky, 211 Lafferty Hall, Lexington, KY 20506-0024, USA; \\ celine.lamb@uky.edu (C.L.); d.vallejo@uky.edu (D.V.-C.) \\ 2 Department of Anthropology, Yale University, 10 Sachem St., New Haven, CT 06511, USA; \\ jacob.welch@yale.edu \\ * Correspondence: scotthutson@uky.edu
}

Received: 17 March 2020; Accepted: 8 April 2020; Published: 14 April 2020

check for updates

\begin{abstract}
This paper reports on heritage initiatives associated with a 12-year-long archaeology project in Yucatan, Mexico. Our work has involved both surprises and setbacks and in the spirit of adding to the repository of useful knowledge, we present these in a frank and transparent manner. Our findings are significant for a number of reasons. First, we show that the possibilities available to a heritage project facilitated by archaeologists depend not just on the form and focus of other stakeholders, but on the gender, sexuality, and class position of the archaeologists. Second, we provide a ground-level view of what approaches work well and which do not in terms of identifying aspects of cultural heritage that are relevant to a broad swath of stakeholders. Finally, we discuss ways in which heritage projects can overcome constraints to expanding community collaboration.
\end{abstract}

Keywords: archaeology; community museums; gender and sexuality; Maya

\section{Introduction}

In framing the contributions to this Special Issue of Heritage, Fisher and Chase endorse Patricia McAnany's suggestion that Maya archaeologists make their work more inclusive in scope and participation. If we do not form what Fisher and Chase call equitable partnerships with local communities, we "endanger the discipline and flirt with societal and academic irrelevance" [1]. Yet, in a provocative paper published 10 years ago, Marina La Salle [2] asked "what if collaboration, despite all of the good intentions of those who are sincerely committed to 'decolonization,' is really just making everyone feel better about continuing an exploitation that may, in fact, be inherent in the system?" In other words, what if partnerships with local communities merely enable archaeologists to continue business as usual: Maintaining access to data that archaeologists then convert into publications that reap financial reward and other forms of currency [3]? Ironically, La Salle [2] notes that the recent explosion of self-reflexive literature on collaborative archaeology represents a new stream of academic revenue though now on a different level, such that archaeologists can double dip, first by publishing on the data and then by publishing on the participatory process by which the data were extracted.

Without question, archaeology is self-serving. Archaeologists recognized nearly 40 years ago that archaeology as a field of production attends not merely to the archaeological record but to contemporary systems of rewards and structures of symbolic capital [4-8]. Nevertheless, we agree with McAnany, Fisher, Chase, and the other contributors to this Special Issue (not to mention several authors cited below) that heritage work can benefit contemporary stakeholders without harming others [9] and without having to solve the world's most pressing problems (cf. [10]).

In this paper, we discuss some of the benefits we have sought to create and what we have learned from stakeholders of an archaeological project in the Northern Maya Lowlands. Despite the growth of 
literature on archaeological heritage and precocious analyses in our corner of the Maya world [11], Ann Pyburn's [12] comment that such work "remains an unremarked and unpublished part of archaeology's oral history" retains a degree of validity for our region. A non-representative sample of 20 "broader impact" statements from Maya-themed National Science Foundation proposals reviewed by the first author shows concern mostly with hiring or training workers and students and disseminating research results among scientists and locals. Though our own work might not be pathbreaking, we hope the following analysis of our successes and failures in going beyond the standards seen in the NSF proposals contributes to "a useful bank of knowledge" [12]. Thus, we focus on the process by which we defined and revised our heritage goals, frankly highlighting the challenges and mis-steps along the way. At present, our goals are not necessarily to valorize traditional culture or to get people to see themselves as "Maya" but to bolster already existing dispositions and discourses on heritage that strengthen people's sense of identity and pride. We interact with multiple overlapping communities that occasionally conflict. Making heritage beneficial to these groups involves accepting forms of disturbance to the archaeological record that might bother the most zealous preservationists and engaging in debates with stakeholders over what a more pragmatic form of preservation should look like. It may also involve recognizing unexpected stakeholders and utilizing new and already established social networks. We are currently planning a pair of exhibits (geared toward local and migrant stakeholders but not tourists), which we hope will provide a resolution to one of these debates and enable collaboration that is relevant to multiple stakeholders. We begin by providing background on the key stakeholders.

\section{Local Stakeholders}

Many different communities have a stake in the results of an archaeology project, including federal and regional officials from Mexico's Instituto Nacional de Antropología e Historia (INAH), domestic and international archaeology enthusiasts, and local communities. Our archaeology project, the Proyecto Arqueológico Sacbé Ucí-Cansahcab (PASUC), began in 2008 and has investigated several ruins along an ancient stone causeway (sacbé in Yucatec Maya) that runs 18km from the ruin of Ucí, the western endpoint, to the ruin of Cansahcab, the eastern endpoint. We follow in the footsteps of Rubén Maldonado Cárdenas, who conducted the first archaeology at these sites as part of the Aké Project from 1979 to 1982. Ucí is the largest of these ruins and its monumental core hugs the south edge of the modern village of the same name. Working at a particular ruin requires permission not just from INAH, but also from landowners. Though ruins are property of the nation as a whole (as defined by the federal government), land is owned privately or by communal land-holding groups (ejidos). Our laborers mostly come from three different places: The villages of Ucí (population 1224) and Kancabal (population 552), and the town of Cansahcab (population 4293). Ucí, located 3km north of the municipal center Motul (population 23,240), was the first place we worked and over the years we have spent by far the most time on Ucí land with Ucí workers. Given this extensive contact, heritage and outreach work takes place primarily in Ucí but also in the villages of Kancabal and Chacabal, in the municipal centers of Motul and Cansahcab, and among migrants in Los Angeles. Many people from this part of Yucatan began migrating to California in the 1990s. Migration reached its peak between 2000 and 2005, due in part to devastating hurricanes and neoliberal agricultural policies in Mexico [13]. Several hundred people originally from Ucí now live in the Los Angeles area and maintain strong connections with their hometown. They have donated tens of thousands of dollars to renovate Ucís Catholic church and pave roads. Many visit Ucí in June during the two-week-long fiesta for the town's patron saint, San Antonio de Padua. Others cannot visit due to US immigration policy but have maintained contact not only with friends and relatives, but also with virtual communities centered around Ucí, such as Facebook groups.

To treat people linked to Ucí as a major group of stakeholders is not to say that this is a single community. Despite strong connections between people living in Ucí and migrants from Ucí living in Los Angeles, several permanent Ucí residents see themselves as distinct from those who migrated. Of course, there are fault lines even within those who live in Ucí year-round, though in our experience, 
these fault lines are more fluid than those seen in famously factionalized villages in Yucatan such as Chan Kom [14-16].

Should we call people from Ucí a descendant community? This question brings up a rich, nuanced discussion. Archaeologically, we see evidence of continuous occupation in Ucí from at least the Late Classic period (including a $700 \mathrm{CE}$ carved vase with the toponym Ukayi) to the conquest, the colonial period, and the present. Archival evidence confirms continuity from the 16th century, when the village was called Ucuyi. Many older people who grew up in Ucí speak Yucatec, the language of the native population at the time of the arrival of the Spaniards and well before. Thus, one can easily posit continuity between contemporary people and the ancient Maya. Yet, oppression, poverty, and spiritual alienation over the last 500 years have disconnected many contemporary people from the deep past [17]. In the face of ethnic discrimination, upwardly mobile people often reject ties to Maya cultural traditions [12]. Other processes of historical severance have been described by Matthews [18] for African American communities in New Orleans and Shackel and Gadsby [19] for working class neighborhoods in Baltimore.

People in rural Yucatan whose ruins have not yet been investigated by archaeologists often say that giants or little people, not ancestors, built the stone mounds recorded on archaeological surveys $[16,20]$. Thus, many contemporary people do not see themselves as descendants. That the term "Maya" as a reference to a group of people is neither ancient nor stable also troubles the prospects for connecting contemporary people to what archaeologists call the ancient Maya. Not found in any pre-Hispanic writing, the word appears very sparingly in the colonial period, almost never written by native Yucatecans as a term of self-reference. In those colonial contexts where the term does appear, people used it as a self-deprecating remark [21] or as an insult to others [22]. In some places, the term Maya still carries derogatory connotations [23,24]. In the 1880s, linguists began using the word Maya more broadly as the label for a family of native languages that included Yucatec and a couple dozen others [25].

Whether they speak Maya or not, people in places like Ucí often do not self-identify as descendants of the ancient Maya. Yet in keeping with the idea that heritage is in motion [26,27], archaeology often contributes to changes in self-identity. By listening to what archaeologists and tourists say about "Maya culture," people living near archaeology projects learn about this new and now positive use of the term "Maya" [12,28,29]. Some come to appropriate the term as a kind of strategic essentialism, particularly in tourist zones where identifying as Maya can help sell handicrafts or fetch higher tour guide tips from tourists in search of authenticity [30]. In other words, public archaeology can create descendant communities and make stakeholders [31]. We find nothing illegitimate in such occasions when archaeology plays a role in leading people to claim the ancient Maya as ancestors. In many contexts, identification with past Maya people requires little or no prodding from archaeologists, as is clear from Maya cultural activism in the highlands of Guatemala and Chiapas [32-36], and the Yucatan peninsula [37]. Furthermore, people can form ethnic identities connected to the past in ways that do not involve archaeology, discursive strategies, or cultural/political activism. For example, Armstrong Fumero [38], using a perspective that highlights the agency of objects, and Hutson [29], using a relational perspective built from the work of Tim Ingold [39], both argue that many rural Yucatecans, prior to contact with archaeologists, do indeed manifest strong connections to the past through interacting with ruins as part of daily life and through making a living from soils and ecosystems similar to those inhabited by the ancient Maya [40].

In the end, whether or not stakeholders from Ucí should be considered descendant communities depends on who speaks and when the conversation transpires. In certain times and places, a speaker's connection to ruins can be as strong as those of contemporary Puebloans who revere archaeological sites not as abandoned ruins but as the lively homes of spirits and ancestors [41-44]. We were lucky that an elder with these views vouched for PASUC at the beginning of archaeological fieldwork. Less important than being a certified descendant community is the issue of being able to identify in some form with the past. A good example comes from Theresa Singleton's work on 19th century African American rice farmers in rural Georgia [45]. Here, the closest biological descendants of the rice farmers 
were less interested in archaeology than were urban professionals who had little to do with those farmers. Another good example comes from Teresa Moyer's work at the Boyne house in Flushing, New York [46], where 21st century Asian Americans find common ground with 17th century Dutch colonists. These examples show that finding a connection between past and present that resonates with stakeholders is more important to the success of a heritage project than the directness of that connection. Finding resonance requires finding relevance.

\section{Finding Relevance, Part 1: False Starts}

If there is a common thread in the growing mass of collaborative, public, ethnocritical, participatory, and community archaeologies, it is relevance. Some of the most vibrant collaborative projects [47-49] are those that adopt a perspective that will resonate with stakeholders. Archaeologists' ideas of ancient heritage often do not resonate among historically oppressed and economically disadvantaged stakeholders preoccupied by the challenge of scraping together a living amidst uncertain local and global economies. Hutson learned this lesson firsthand while doing doctoral fieldwork at the ruin of Chunchucmil 20 years ago. Based on the good intentions of the now-deceased project director, an idea circulated that local communities would benefit from converting a part of the ruin to a museum with live displays of traditional culture. The idea had several flaws, only two of which we mention here [50]. First, tourism can be an empty promise [51]. Most tourist income in the Maya area does not go to villagers [52,53] and archaeo-tourism developments like the Mundo Maya Organization can disempower native Maya communities [54-56]. Furthermore, the market for archaeological tourism is saturated. In the state of Yucatan, dozens of archaeological sites are already open to the public, yet only the most spectacular attract significant numbers of visitors. Second, and more importantly, the museum idea went against local interests because, in a village whose livelihood is centered not on maquiladoras nor migration but on the land itself, it threatened to take away land [57]. As a result, the museum idea went nowhere and created rifts that took intensive effort to repair.

Thus, when Hutson initiated PASUC, he wanted heritage work to align with stakeholders' own economic, intellectual, and/or emotional goals. Early conversations at village meetings and informal chatting suggested a common ground between past and present that we thought would make the archaeology relevant: Mobility. The construction of the $18 \mathrm{~km}-$ long causeway, unusual in the past, indicated that mobility was important for several ancient actors. Mobility also intersects with contemporary livelihoods. Given mass migration from Ucí to Los Angeles, mobility is an economic juggernaut and a critical aspect of the emotional experience of stakeholders. Thus, mobility seemed to articulate directly with pressing contemporary concerns. Initial conversations in Ucí showed that people who had lived in the United States and migrants who were visiting Ucí from the United States during the patron saint fiesta could be quite passionate about archaeology.

Having read that diasporic Irish Americans expressed more excitement about Charles Orser's 19th century Irish potato famine project than did people in Ireland [45], Hutson began making contacts in Los Angeles. This was easy thanks to the Red de Clubes Yucatecos USA (Network of Yucatec Clubs), which holds an annual vaqueria, a fiesta with folk dancing, in Los Angeles. In the September 2010 vaqueria, PASUC received permission to set up an information booth about Motul-area archaeology just inside the entrance and across from the beer counter. Any of the nearly 500 people who attended could see us, and lots of people were interested. Behind the beer counter, the younger brother of one of the men who works with us in the field in Ucí had posted a cardboard sign with the words "Saludos a Ucí desde Los Angeles" (Greetings to Ucí from Los Angeles). This gave us the idea of starting a web blog, at least partially centered on heritage, where such messages could be accessed by people on both sides of the border. The blog, called ¡Sacbé!, ran in English and Spanish and gained some readers in both the US and Mexico (http://sacbeob.blogspot.com) but Hutson abandoned it after a few months for several reasons.

One of the reasons for the failure of the blog was that in late 2010, few people in Ucí were online. Smartphones were not widespread and almost nobody in the village had an internet connection. So, a web-based bulletin board could not really link people virtually across a border, regardless of whether 
heritage was involved. Today things are very different. The availability of cellular connectivity within even the smallest communities in the Peninsula, and the proliferation of communication platforms, such as Facebook and Whatsapp, permitted new ways of interaction with all members of Ucí, abroad or still living in the community. Ucí-specific Facebook groups ("Ucí siempre Ucí") have become essential in community organization, but also in highlighting aspects of the community, which are seen as critical in perpetuating the notion of an Ucí identity. Aside from major collaborative projects, such as paving contemporary roads, this platform is also used, for example, to organize fundraisers to repatriate bodies of migrants who have died in the USA. Given the cost and complication of this process, this is seen as a burden that can be placed on the community as a whole no matter their place of residence. When we asked about the best way to publicize a public talk, we were directed specifically to the Facebook group. When we asked why, some of the reasons given were that this included the community in the USA in activities and decisions made within Ucí. Another reason was that most people from Ucí no longer work there, and therefore only spend a limited amount of time within the actual community. The public talks given in Ucí were recorded and uploaded to the Facebook group. This sparked even more conversations and questions, which can be addressed through further collaborative research.

The blog also failed simply because it did not have much buy-in. Hutson came up with the idea, not stakeholders, and Hutson's own positionality at the time (father of a newborn) reduced the time needed to network it more closely with stakeholders. More broadly, stakeholders' receptions of the idea of mobility as heritage were mixed. Older people who had spent a lifetime working the land and therefore knew a lot about the sacbé and other archaeological features were excited about the heritage of mobility. Younger people seemed interested, but conversations about causeways and movement did not go very far. Younger people's lives were hugely impacted by migration (even those who did not migrate), but they did not bring up, on their own, the connection between past and present movement. What were people bringing up on their own, and how could these interests be integrated into a more participatory framework?

\section{Finding Relevance, Part 2: Positionality and Place-Based Engagement}

As Ann Pyburn [58] has repeatedly stressed, ethnography can provide the best opportunity for understanding stakeholder interests and standpoints. In PASUC's first decade, we missed several ethnographic opportunities simply because we decided to live in Motul as opposed to living in a village. Motul was convenient (it had internet, banks, large stores, more choices of houses to rent) but in Motul, located just $3 \mathrm{~km}$ from the large site of Ucí, most people were unaware of the ruins. Thus, we missed multiple chances to spend time, as participant observers, in stakeholder communities. Perhaps what we most missed was a chance to get a deeper understanding of stakeholder standpoints [1]. In repurposing feminist standpoint theory to the field of cultural heritage, Allison Wylie $[59,60]$ argues that groups that have been subjected to domination and oppression, such as Canadian First Peoples, "may know different things or know some things better than those who are comparatively privileged." Standpoint theory also nudges privileged academic analysts like ourselves toward recognizing the contingency of our own points of view and where they come from. Two of us finally lived in Ucí during the most recent field season, not in an archaeological camp at the edge of the village nor an ex-hacienda set apart from the village, but in a modest house by the main square. In this context, setting up a ceramic table out front resulted in so many casual conversations with passersby that it was hard to get work done. Yet, this is not a downside if we view process to be as important as product. In previous seasons, we hosted lab tours in Motul to increase transparency about what we do with artifacts, but having the artifacts out on tables in Ucí, all day long, visible to any passerby, greatly increased conversations about heritage. Placing the ceramic lab out in the open within Ucí created a learning environment, which could be largely determined by the local inhabitants. By hosting a de facto "open house" day after day, the multiple stakeholders within the community could determine the nature (e.g., time, duration, content) of the interactions themselves. This is vastly different from more "traditional" forms of community engagement, such as public talks, which usually follow archaeologists' schedules and leave little to 
no room for further conversations. These interactions were vastly productive given that they allowed us to reach multiple age groups and people with different degrees of knowledge about archaeology. The themes and questions brought up during these daily interactions heavily influenced other forms of public outreach within the community.

Public talks hosted by Vallejo-Cáliz within Ucí addressed many concerns brought up during these closer conversations. Aside from being curious about the archaeology within their community and our own specific investigations, many community members also mentioned that they wanted us to investigate local folk tales and the pre-Hispanic to Colonial transition. These are excellent foundations for future collaborative work. We also learned from these exchanges the importance of an interpretive display in Ucí and the interest in similar exhibits among parties outside of Ucí. We discuss our initial steps towards such projects in the final section below.

Living in the village, even for a relatively short time, made it extremely easy to be part of village life: Attending weddings and fiestas, participating in milpa burns, becoming a regular at small businesses, buying panuchos at the templo. We could effectively shelve the rental car. We had been eager to do this ever since someone from Ucí put a rock through the windshield of a rental parked on the edge of the village during fieldwork in 2016. Ditching the car also affected our positionality. Most people in Ucí do not have cars. Walking (or riding on the back of someone's motorcycle) to the ruins and everywhere else in the village puts us on the same level as most villagers at least in terms of transit. Of course, our privileged position as employers, as credentialed specialists, and as outsiders with access to extensive resources means that we occupy very different, potentially neo-colonial spaces. Yet there are ways of softening these power differentials: Lift rocks in the field just like workers do, share your food as they share with you, or make jokes at your own expense.

At the same time, positionality of both archaeologists and villagers can prevent the kind of ethnographic opportunity just described. Literature on heritage work often highlights the diversity and complexity present within collaborating communities, while downplaying the distinct backgrounds, sensibilities, identities, and personalities of researchers. If ethnography, and consequentially heritage work, entails bridging (or softening) a distance between the archaeologists and field collaborators, then various aspects of one's identity can "figure prominently in the scholarly product" [61]. Furthermore, if achieving "closeness" with collaborators is one essential aspect of positive heritage exchange, then those "more distant" from societal or disciplinary norms face additional challenges in order to form genuine or meaningful relationships with community members. Welch experienced several challenges navigating community relations as a gay, cis-gendered male. Despite the immeasurable generosity of local collaborators, who hosted him in their homes numerous times for dinners and parties, Welch's concealment of his sexuality paired with the numerous homophobic remarks overheard during fieldwork prevented him from forming genuinely close relationships with collaborators. While Hutson and Vallejo-Cáliz experienced positive aspects of living within the town, the fear of ostracism and the negative consequences of being outed caused Welch to distance himself from the community to help maintain secrecy. This is consistent with many gay and lesbian anthropologists who must manage their identity and maintain constant hypervigilance during research, which can create painful experiences in the field and lower one's self-esteem $[61,62]$. At no time during fieldwork did a community member express tolerance of gay people, relationships, or activities.

Lamb's positionality also shaped the ways in which, and the places where, she engaged with Ucí community members. In 2016, Lamb lived in the area on her own for three months to conduct lab work. Not being able to afford a rental car, she planned to rent a house a few blocks from the Ucí center, where the project materials were stored, which would also allow her to get to know the community better. Yet, on days when it was necessary to visit a ceramic lab in Merida, part of the commute would involve walking or hitchhiking on a back road in the dark. While Lamb had never experienced gender-based violence in this region, she chose to live in Motul to avoid risk. These anxieties loomed in shaping her quotidian mobility, yet she recognizes that her experiences demarcate moments of privilege based on citizenship, class, and race (allowing her to easily cross the Mexico-US border, afford formalized 
international travel, win grants paying for research expenses, access higher education institutions). However, they also underline how mobility and the use of particular places are forms of exercising or leveling power based on hierarchies of gender [63] as well as sexuality.

While doing lab work in Motul, however, Lamb was able to engage in discussions of heritage that differed from those she had during fieldwork in Ucí. For two months, she mainly worked with five women, three of which were from Ucí and two of which were from Motul. The lab consisted of the small patio and one room of a house. It was in this restricted place that Lamb felt she had some of the most meaningful encounters within a work context. Compared to conversations with most men in the field, conversations with these women were more varied in topic and allowed us to learn more about each other. Additionally, when family members of the lab-workers came to get them in the afternoons, they often arrived early and would sit and chat with Lamb about the work being done. When conducting fieldwork, there were no such possibilities for Lamb to meet the fieldworkers' families. Lamb suspects that interactions with the lab-workers were shaped by gender, place, and type of work. For example, in the lab, each of us undertook similar tasks. This differs from fieldwork where there is a clear distinction between field supervisor - the only one to take photos, draw, or fill out paperwork-and excavators. While we differed in age, class, race, profession, and marital status, our identities as women may have made it easier to establish rapport. Wesp and coauthors [64] note that foreign female archaeologists in rural Mexico are often liminal: "neither fully female nor male, with female bodies and male behaviors". While Lamb may have been perceived as liminal-unlike most women her age in rural Yucatan, she smokes cigarettes and has no children, for example-she nevertheless performed her gender in an intelligible way by engaging in lab work, a kind of labor that is often gendered female [65] and seen as an extension of the domestic sphere. The kind of work done and where it took place, in Lamb's own perspective, enabled a social and physical proximity that was enhanced by shared gender, leading to more organic discussions of our own preoccupations. These women are the people Lamb has kept in touch with most frequently, both when returning briefly to Ucí in 2019 but also through social media. Lamb views these kinds of interactions as the basis for future conversations about heritage and meaningful collaboration that is inclusive of women in Ucí.

\section{Finding Relevance, Part 3: Collaboration}

As the first decade of the new millennium closed, archaeologists made persuasive arguments for expanding collaboration-for following interests that stakeholders brought up on their own [66-68]. In this context, we sought to situate PASUC at a different place on the collaborative continuum than what one commonly sees in broader impact statements within Maya-focused NSF proposals: Doing outreach and hiring and training students and workers. Despite La Salle's thoughtful critique of collaboration (see above), we believe it can be something other than a soft-power marketing strategy for continuing the extraction and exploitation of archaeological resources. We lack the space for a comprehensive defense of collaborative archaeology and a disambiguation of the different approaches that fall under the umbrella of collaboration. Nevertheless, we note that 1 ) indigenous voices (not just archaeologists seeking to expand academic currency) have been central in the push for collaboration; 2) this push predates the recent explosion of literature on the subject; and 3) these voices were insistent enough to enshrine the establishment of "equitable partnerships" between archaeologists and indigenous peoples in the World Archaeology Congress' First Code of Ethics in 1990. In the Maya area, Maya people themselves demand collaboration [32]. In Mexico, where heritage discourses have historically been shaped to support the goals of the state, anthropologists have called for a "framework governing the use of Mexico's heritage that is less exclusive and centralistic, more democratic and participatory" [69].

For us, part of increasing democracy was to recognize the partiality of our own perspectives and not let our habitual standpoints silently guide decisions about running an archaeology project. For example, it is common for archaeologists to spend money on an end-of-the-year party with those most closely involved; but is this what everyone actually wants? After opening this to a discussion, we found one year that the workers preferred to pocket the money earmarked for the party instead of 
actually having the party. So, that year, we skipped the party and gave out cash. One particular habit that we did not succeed in shaking was the gendered division of labor, in which men do fieldwork and women wash sherds, cook, and clean. Welch once asked a local male leader if any women would like to excavate and was told no. Though this answer may not reflect the views of some of the women the leader was speaking for, we had accidentally disturbed local gender ideologies in 2011 regarding a men-only shamanic ceremony [26] and we did not want to do so again. The idea that some women do indeed want to work in the field is supported by Traci Arden and Julie Wesp, who ran a field season in the village of Cacalchen (Municpality of Yaxcaba, Yucatan) with a female-majority workforce. While the women faced scrutiny in town for rebelliously working in a masculine domain, the project afforded them a chance at entering the cash economy, enhanced their social mobility, and increased opportunity for their children in school [64]. We add that when women are not able to do fieldwork, they miss important aspects of cultural heritage management. Likewise, by not working in the lab, men miss cultural heritage engagements such as the intimate experience of artifacts that comes from cleaning them. When Lamb hired a young man for lab work, none of his female counterparts appeared fazed by his presence, suggesting that certain aspects of the gendered division of archaeological labor may derive as much from the project's assumptions as they do from local gender norms.

To get back to the question of participation in heritage, what did people bring up on their own regarding the history, prehistory, or landscape of Ucí? When asked during the first years of the project (2008-2010), many interlocutors demurred, an experience not uncommon in these kinds of conversations [70]. When people did speak directly to the question, they usually gave one of two answers: Caves and material things (ranging anywhere from fossilized shells in the local limestone to ancient pottery to buried treasure). Caves were something of a non-starter in terms of a community-based archaeology project due to a lack of caves with archaeological deposits; caves loom larger in folklore. Material things, of course, contain lots of potential for a heritage project, and this is what we are most focused on at present (see below). As a result of the more extensive community ties that came from living in Uci, we learned of stakeholders' interests in folk tales and the pre-Hispanic to Colonial transition. Ten years ago, however, an opportunity for collaboration presented itself in the form of a grant from the Maya Area Cultural Heritage Institute (MACHI; see [1]).

The MACHI grant supported a variety of activities involving art, archaeology, food, education, and the heritage of rural Yucatecan livelihoods. Elsewhere, we have written specifically about the MACHI grant [26]. Here, we highlight that which is most germane to the central goal of the present paper: A critical reflection on the evolution of our ideas for how heritage can benefit stakeholders. In terms of collaboration, the project was a success. The planning included community members from the beginning and an unforeseen series of entanglements permitted a wide variety of actors to use the activities as vehicles for furthering their own goals. One of the highlights was an event that helped democratize the discourse on ancient heritage. Borrowing an idea from Lisa Overholtzer [71], we held a symposium in which people from Ucí working on the archaeology project gave their own presentations to the rest of the village, highlighting what they thought was important about what they were uncovering with their own labor. Our archaeology project has been less collaborative than our MACHI project, yet given our context and experience, a completely mutual, community-based participatory research (CBPR) program of archaeological investigation would be difficult to achieve. This has also been the case in situations where outside researchers have had extensive time to lay the groundwork for such an enterprise [70,72]. The non-representative sample of 20 NSF proposals reviewed by the first author contains no CBPR projects.

Our approach to heritage during the MACHI grant had missteps and missed opportunities. The ones we want to highlight both arise from a stated premise of the project: "to preserve both ancient landscapes and traditional cultural practices" [26]. A potential misstep here is that traditional cultural practices should not necessarily be coupled with ancient heritage [12]. In the eyes of many urbanites in Yucatan, "traditional cultural practices" are associated with poverty and backwardness. Linking ruins with traditional culture can potentially alienate people with roots in Ucí who appreciate ruins 
but want to avoid the negative stereotype of being traditional. Yet, as we discuss further below, some residents of Ucí have specifically voiced an interest in both.

Regarding preserving ancient landscapes, we felt the issue was straightforward. We thought we could diminish destruction of ancient mounds by stressing at several public events that such mounds, found all over Ucí and beyond, are actually community archaeological resources. This turned out to be a missed opportunity. If anything, destruction of these and other small archaeological features actually increased in the years following the MACHI grant. In 2016, we found that a landholder with extensive property had leveled over a dozen house platforms to install a center-pivot irrigator. Seeing this and other desultory acts of destruction, we applied for a grant for emergency excavations of two mounds in 2017 that were at high risk of being destroyed. The missed opportunity, however, was not that the integrity of archaeological features continued to be compromised. Rather, we missed an opportunity to open a conversation about preservation-a complex issue with lots of grey area-and get standpoints different from our own.

Our own standpoints on preservation have changed over the course of the project. Initially, we favored keeping archaeological sites as intact as possible. This meant that in conversations with people who had antiquities in their houses, we tried to underplay the value of these antiquities to discourage additional collecting. However, this attitude can be colonial, implying that outsiders' ideas about how the past should be used trump how locals value the past. After reading more about collectors [73] and getting a better sense, both through conversations with people from Ucí and through academic writing about other Yucatecans [13,38], of the powerful tie between antiquities and identity in Yucatan, our standpoint changed. Certainly, we do not want to encourage people to dig things up, but we have to recognize that in a village embedded among mounds (common in Yucatan), people will inevitably unearth artifacts. As one worker, a staunch supporter of the PASUC project and enthusiast of ancient Maya culture, told Lamb when discussing the conflict between protecting the mound in his house lot and his need for space to grow garden crops, "ipero hay que vivir!" (but one has to live!). The cynic would say that when archaeologists choose to engage warmly with such amateur collectors, they engage merely to preserve good relations with locals, which perpetuates access to ruins and thus serves archaeologists' own extractive interests. However, that is not the full story.

In 2010, a migrant who had returned to Ucí from California stated that tangible things from his homeland, be they ruins or a fossil seashell embedded in limestone, give him pride when speaking with migrants from other parts of Mexico and Central America. Deanna Barenboim [13] writes similarly about cheap mementos such as plaster casts of the Castillo at Chichén Itzá:

"Such objects may become especially effective moorings for indigenous peoples who have faced legacies of dispossession dating back to colonialism and that persist through the neocolonial realities of contemporary transnational migration. For migrants to decorate their California homes with "a little Chichén Itzá" is thus no small matter. Indeed, such everyday engagements and creative repurposing of ordinary objects assert migrants' custodial rights to Maya heritage itself."

In the last two seasons of archaeological fieldwork, we have held tours of excavations within the village of Ucí in June, precisely when many migrants have returned to Ucí for the patron saint festival. These tours were boosted by the fact that they were inside the town (an easy walk for people of all ages) and that attractive and well-preserved buildings had been uncovered. The amount of excitement and passion on these tours far exceeded our expectations. Nearly everyone was taking archaeological selfies. We believe this enthusiasm shows that the ruins facilitate emergent senses of pride in one's homeland and perhaps in a Maya ethnic identity. Returning to standpoints of preservation, many visitors are dismayed that we need to re-bury the buildings we expose. Archaeologists argue that burial is what permitted them to survive for thousands of years, and reburial is a requirement of our permit from INAH. Some stakeholders, both migrant and non-migrant, do not like this reasoning. We have brought many stakeholders by bus to ruins like Chichén Itzá and Mayapan and they recognize that their own mounds, once cleared and restored, are also worth visiting. The compromise we are working on is a permanent archaeological display in Ucí itself. 
Non-migrants also have pride in their ruins, sometimes engendering an ethic of preservation, even when there might not be an explicit sense of ethnic connection [74]. There is a long tradition in Ucí and elsewhere in rural Yucatan [38] of bringing artifacts (figurines, metates, distinctive pottery, stone points) from ancient houses to modern houses. Rather than seeing this as archaeological destruction, ${ }^{1}$ this can be seen as a way in which contemporary villagers build meaningful connections to the ruins and artifacts found in their fields and house lots. Such connections can lead to a desire to protect ruins on a larger scale. In contrast to major looting elsewhere in the Maya area, the largest mounds at Ucí have not been looted (though some were disturbed for roadbuilding fill in the 1950s).

As mentioned above, our current heritage goals focus on archaeological displays and interactive events. Lamb was approached in 2017 by Jared Barroso, director of Motul's Imagine Cultural Center, who was interested in housing an exhibit on Ucís archaeology. Barroso explained Imagine was expanding their free educational and cultural initiatives for younger audiences and, as she stated half-joking, she wanted people to realize Motul has much more to offer then its famous dish, huevos motuleños. Barroso arranged follow up meetings in 2019 with several people beyond Lamb's own network, including 1) Cesar Ochoa Torres, an archaeologist in Yucatan interested in learning more about community engagement, to brainstorm a collaborative project; 2) two members of Rotary Club Merida Norte, which is creating the Museo del Arbol in Ucí to promote reforestation and biological diversity, and 3) Luis José Chan Sábido, a professional violist and president of Kunst and Music Yucatan, an association that creates artistic and educational programming in Yucatan as well as intercultural exchanges. Lamb also met with Seidy Ramírez Mérida, a primary school teacher in the nearby village of Tanya and daughter of a project cook, who voiced interest in having Tanya schools access the potential exhibit, which could serve as a tool for other learning outcomes. In these meetings, Lamb explained her desire to showcase the rich history of Pre-Columbian residents of Ucí and its ejido lands since many had voiced such an interest. She also hoped that, through an interactive exhibit using local examples, the archaeological process (including methods and interpretations) could be demystified. This last interest stems from Stottman's [75] argument that, by having basic knowledge on what archaeology is and how it is done, communities can better understand its "potential to be used to their own benefit."

The common ground among the varied interests and skills within this group was creating a youth-focused educational exhibit using local archaeological Maya heritage that would incorporate paleo-environmental and performing arts (through, for example, ancient musical instruments or dance paraphernalia) components and include multi-sensorial activities. Furthermore, everyone agreed that exhibits and related activities should be mobile and find their way to other towns, yet be housed in, and centered on, Ucí (and could be integrated into the possible museum Vallejo-Cáliz has planned, described below). While none of these individuals were from Ucí, they all demonstrated an interest in its archaeology as a content base for their own goals, and some were already involved with the Ucí community.

The next step is to involve stakeholders from Ucí and create a brief proposal, flexible enough to be modified, if not scrapped entirely, based on the concerns of Uci's residents. Questions concerning the broader community objectives, topics covered, materials used, and who is to be considered a collaborator, still need to be addressed. For example, would agriculture, hunting, and "traditional" foods be relevant topics to younger generations, who are increasingly less involved in these activities? Would residents be amenable to sharing a mobile exhibit with nearby towns? Recent successful archaeology-based public outreach events, like ArqueoFest 2019 [76], and "Vamos a Hablar de Yaxuna", included experiential, multi-sensorial activities using 3D models, modern materials, and visual media. Would residents be as interested in such materials, since some have expressed wanting to see displays of artifacts recovered from excavations? What roles would community members want to take within

1 The Consejo de Arqueologia's policy of allowing people to keep antiquities found on their land, provided that owners register the antiquities with the regional INAH center, implicitly recognizes this point. 
planning and building an exhibit? Are any of the "outsider" stakeholders (including archaeologists) entrenched in local socio-political or economic factions that might lead to certain voices being excluded?

The proposal will be shared in various ways in summer 2020. Rather than relying solely on ejido gatherings (mostly attended by older men), invitations to a community forum will be given out door to door, outside of schools and churches, hung in public spaces and shops to access Ucí's diverse population, which will include a few sentences summarizing the proposal. Individuals will thus have the chance to think about the proposal before talking about it in person. Lamb is also considering organizing in the meantime a small event on "What is Archaeology?", with various activity stations using representative archaeological materials, modern fauna and flora, printed maps, etc. This event would allow for quick anonymous surveys and spark conversations concerning what people really want out of a future exhibit or event.

While living in Ucí, Vallejo-Cáliz carried out a series of talks and conversations during the summer of 2019 aimed at various groups. These included both talks in the main square open to the general public and talks with community organizing institutions like the comisaría ejidal. These institutions should not be ignored given that they have served as the primary link with Municipal, State, and Federal authorities since the 1930s. They have also helped remedy conflict between members of the community. The comisaría ejidal has served as a major entry point for engaging with the community, getting permission for fieldwork on local land, and finding workers. One of the most important outcomes of Vallejo-Cáliz's conversations has been that many people in Ucí would like to create a museum space for exhibits that are not at all limited to archaeology. We currently rent (and have invested in improving) a space from the comisaría ejidal and many people see this as a potential museum location.

Some young adults who have participated as local liaisons and field workers with PASUC have mentioned that it is important to merge both archaeological and contemporary Maya practices (sometimes glossed as traditional culture) and display them in the same space. They believe that this would help bridge the gap between ancient and modern Maya, and drive people to take pride in their language and cultural practices [see also 17]. Collaboration in designing such exhibits would mean that members of the community are no longer passive recipients of knowledge produced by "professional" archaeologists. They become active, ask questions, and demand information that may be sourced through archaeological methods. In this sense, the goal will be to discover the history of Ucí together, creating a story or narrative akin to their own experience in the world and their own place in the history of the site. Our own interpretations are openly and publicly discussed, not just delivered and accepted as the/a truth.

\section{Conclusions}

Positionality and place (including the various meanings attached to a place and created by various actors) shape discussions of heritage and heritage engagement. This means that if archaeologists become partners in such endeavors, the diversity of their experiences and the experience of their local collaborators must also be considered. Positions shaped by gender and sexuality can affect the kinds of heritage experiences that are possible. If positionality factors in heritage work, grading "positive" outcomes is less straightforward given the individual ways people form common ground between locals and researchers. Thus, to the extent that one's positionality makes it possible, spending less time on what McAnany calls the "quiet jungle path" [1] and more time among diverse interest groups can bring new possibilities, yet also potential challenges and drawbacks. Of course, it is easy to talk with stakeholders about cultural heritage projects, but the positionality of various actors (for example, a graduate student rushing to finish a dissertation) can make it difficult to put these ideas in place.

Moreover, our experiences over time have highlighted the deficiency of catering heritage initiatives to what we assume may be a homogenous stakeholder community, be it imagined, physically circumscribed, or attached to the archaeological site in question. Opportunities for heritage discussions may come from unexpected people and contexts (workdays in a Motul lab; passersby in Ucí; people and organizations well beyond our own personal networks). By supporting stakeholder groups who 
intentionally converge around a heritage project and are made up of individuals of overlapping communities, diverse local perspectives and skills may be included and finding local relevance is more likely. Some people in Ucí have voiced interests in displaying ancient Maya history in tandem with contemporary yet traditional culture. At the same time, other stakeholders might resist the conflation of ancient Maya history and present-day rural traditions [12]. Either way, local stakeholders are knowledgeable authors of their own heritage, rather than hoodwinked audiences, and such disagreements allow for a pluralistic, contingently situated community to emerge, enriching theories of cultural representation, heritage, and community along the way.

As PASUC comes to a close, and the archaeologists vacate their role as employers, we may be better positioned to take on collaborative initiatives. Many people in and from Ucí are deeply invested in their history, though no single preservation solution pleases everyone. Some local stakeholders want buildings preserved for all to see while archaeologists from beyond Ucí believe that re-burying excavated buildings is the best current option for preserving them. The different exhibits (both in and beyond Ucí) that many stakeholders envision and that Lamb and Vallejo-Cáliz plan to pursue will hopefully achieve an array of goals defined by people both in and beyond the village whose ruins started all of this in the first place.

Author Contributions: Conceptualization: S.H., C.L., D.V.-C. and J.W.; Investigation: S.H., C.L., D.V.-C. and J.W.; Writing: S.H., C.L., D.V.-C. and J.W. All authors have read and agreed to the published version of the manuscript.

Funding: The PASUC archaeology project has received support from the National Science Foundation (NCS-106336), the Waitt Foundation, the Wenner Gren Foundation, The Maya Area Cultural Heritage Institute, Dumbarton Oaks Research Library and Collections and the University of Kentucky College of Arts and Sciences and the Vice President for Research.

Acknowledgments: Archaeology was conducted under permits from the Consejo de Arqueología, INAH.

Conflicts of Interest: The authors declare no conflicts of interest.

\section{References}

1. McAnany, P.A. Maya Cultural Heritage; Rowman and Littlefield: Lanham, MD, USA, 2016.

2. La Salle, M.J. Marina Community Collaboration and Other Good Intentions. Archaeologies 2010, 6, 401-422. [CrossRef]

3. Nicholas, G.P.; Hollowell, J. Ethical Challenges to a Postcolonial Archaeology: The Legacy of Scientific Colonialism. In Archaeology, Capitalism: From Ethics to Politics; Hamilakis, Y., Duke, P., Eds.; Left Coast Press: Walnut Creek, CA, USA, 2006; pp. 59-82.

4. Bourdieu, P. Homo Academicus; Nice, R., Ed.; Stanford University Press: Stanford, CA, USA, 1988.

5. Gero, J.M.; Lacy, D.M.; Blakey, M.L. The Socio-Politics of Archaeology; Research Reports Number 23; Department of Anthropology, University of Massachusetts: Amherst, MA, USA, 1983.

6. Shanks, M.; Tilley, C. Social Theory and Archaeology; University of New Mexico Press: Albuquerque, NM, USA, 1987.

7. Tilley, C. Discourse and Power: The Genre of the Cambridge Inaugural Lecture. In Domination and Resistance; Miller, D., Rowlands, M., Tilley, C., Eds.; Routledge: London, UK, 1989; pp. 41-62.

8. Wylie, A. Comments on The Socio-Politics of Archaeology: The Demystification of the Profession. In The Socio-Politics of Archaeology; Joan, M., Gero, D.M.L., Blakey, M.L., Eds.; Research Reports Number 23; Department of Anthropology, University of Massachusetts: Amherst, MA, USA, 1983; pp. 119-130.

9. Arnold, B. The Past as Propaganda: Totalitarian Archaeology in Nazi Germany. Antiquity 1990, 64, 464-478. [CrossRef]

10. Dawdy, S.L. Millennial Archaeology: Locating the discipline in the age of insecurity. Archaeol. Dialogues 2009, 16, 131-142. [CrossRef]

11. Castaneda, Q. Museum of Maya Culture: Touring Chichen Itza; University of Minnesota Press: Minneapolis, MN, USA, 1996.

12. Pyburn, K. Anne, Engaged Archaeology: Whose Community, Which Public? In Global Public Archaeology; Matsuda, A., Okamura, K., Eds.; Springer: New York, NY, USA, 2011; pp. 29-41. 
13. Barenboim, D. Reclaiming Tangible Heritage: Cultural Aesthetics, Materiality, and Ethnic Belonging in the Maya Diaspora. J. Lat. Am. Caribb. Anthr. 2018, 23, 1-18. [CrossRef]

14. Goldkind, V. Social Stratification in the Peasant Community: Redfield's Chan Kom Reinterpreted. Am. Anthr. 1965, 67, 863-884. [CrossRef]

15. Re Cruz, A. The Two Milpas of Chan Kom; SUNY Press: Albany, NY, USA, 1996.

16. Armstrong-Fumero, F. Elusive Unity: FActionalism and the Limits of Identity Politics in Yucatan, Mexico; University Press of Colorado: Boulder, CO, USA, 2013.

17. McAnany, P.A.; Parks, S. Casualties of Heritage Distancing: Children, Ch'orti' Indigeneity, and the Copan Archaeoscape. Curr. Anthr. 2012, 53, 80-107. [CrossRef]

18. Matthews, C. The Location of Archaeology. In Ethnographic Archaeologies; Castaneda, Q., Matthews, C., Eds.; Altamira Press: Lanham, MD, USA, 2008; pp. 157-182.

19. Shackel, P.A.; David, A.G. "I Wish for Paradise": Memory and Class in Hampden, Baltimore. In Collaboration in Archaeological Practice; Colwell-Chanthaphonh, C., Ferguson, T.J., Eds.; Altamira Press: Lanham, MD, USA, 2008; pp. 225-242.

20. Redfield, R.; Alfonso, V.R. Chan Kom: A Maya Village; Carnegie Institute of Washington Publication No. 448; Carnegie Institute of Washington: Washington, DC, USA, 1934.

21. Restall, M. Maya Ethnogenesis. J. Lat. Am. Anthr. 2004, 9, 64-89.

22. Roys, R.L. The Indian Background of Colonial Yucatan; Carnegie Institution of Washington: Washington, DC, USA, 1943.

23. Castaneda, Q. "We are not Indigenous!" An Introduction to the Maya Identity of Yucatan. J. Lat. Am. Anthr. 2004, 9, 36-63. [CrossRef]

24. Hervik, P. Mayan People Within and Beyond Boundaries; Harwood Academic Publishers: Amsterdam, The Netherlands, 1999.

25. Schackt, J. The Emerging Maya: A Case of Ethnogenesis. In Maya Survivalism; Hostettler, U., Restall, M., Eds.; Verlag Anton Saurwein: Markt Schwaben, Germany, 2001; pp. 3-14.

26. Hutson, S.R.; Can Herrera, G.; Chi, G.A. Maya Heritage Entangled and Transformed. Int. J. Heritage Stud. 2014, 20, 376-392. [CrossRef]

27. Smith, L. The Uses of Heritage; Routledge: New York, NY, USA, 2006.

28. Breglia, L.C. Monumental Ambivalence: The Politics of Heritage; University of Texas Press: Austin, TX, USA, 2006.

29. Hutson, S.R. Dwelling, Identity and the Maya: Relational Archaeology at Chunchucmil; Altamira: Lanham, MD, USA, 2010.

30. Medina, L.K. Commoditizing Culture: Tourism and Maya Identity. Ann. Tour. Res. 2003, 30, 353-368. [CrossRef]

31. Shackel, P.A. Working with Communities: Heritage Development and Applied Archaeology. In Places in Mind: Public Archaeology as Applied Anthropology; Shackel, P.A., Chambers, E.J., Eds.; Routledge: London, UK, 2004; pp. 1-18.

32. Cojti Ren, A. Maya Archaeology and the Political and Cultural Identity of Contemporary Maya in Guatemala. Archaeologies 2006, 2, 8-19.

33. Montejo, V.D. The Pan-Mayan Movement, Mayans at the doorway of the new millennium. Cult. Surviv. Quar. 1997, 21, 28-31.

34. Montejo, V.D. Maya Intellectual Renaissance: Identity, Representation and Leadership; University of Texas Press: Austin, TX, USA, 2004.

35. Fischer, E.F.; Brown, R.M. Maya Cultural Activism in Guatemala; University of Texas Press: Austin, TX, USA, 1996.

36. Gossen, G.H. Maya Zapatistas Move to the Ancient Future. Am. Anthr. 1996, 98, 528-538. [CrossRef]

37. Castañeda, Q.E. Heritage and Indigeneity: Transformations in the Politics of Tourism. In Cultural Tourism in Latin America: The Politics of Space and Imagery; Baud, M., Ypeji, A., Eds.; Brill: Leiden, The Netherlands, 2009; pp. 263-296.

38. Armstrong-Fumero, F. Words and Things in Yucat'an: Poststructuralism and the Everyday Life of Mayan Multiculturalism. J. R. Anthr. Inst. 2011, 17, 63-81. [CrossRef]

39. Ingold, T. The Perception of the Environment: Essays on Livelihood, Dwelling, and Skill; Routledge: London, UK, 2000.

40. Pearson, M.P. Public Archaeology and Indigenous Communities. In Public Archaeology; Merriman, N., Ed.; Routledge: London, UK, 2004; pp. 224-239.

41. Watkins, J. Beyond the Margin: American Indians, First Nations, and Archaeology in North America. Am. Antiq. 2003, 68, 273-286. [CrossRef] 
42. Watkins, J. Communicating Archaeology: Words to the Wise. J. Soc. Archaeol. 2006, 6, 100-118. [CrossRef]

43. Adler, M.; Bruning, S. Navigating the Fluidity of Social Identity: Collaborative Research into Cultural Affiliation in the American Southwest. In Collaboration in Archaeological Practice: Engaging Descendant Communities; Colwell-Chanthaphonh, C., Ferguson, T.J., Eds.; Altamira: Lanham, MD, USA, 2008; pp. 35-54.

44. Nicholas, G.P.; Welch, J.R.; Yellowhorn, E.C. Collaborative Encounters. In Collaboration in Archaeological Practice; Colwell-Chanthaphonh, C., Ferguson, T.J., Eds.; Altamira Press: Lanham, MD, USA, 2008; pp. $273-298$.

45. Singleton, T.A.; Orser, C.E., Jr. Descendant Communities: Linking People in the Present to the Past. In Ethical Issues in Archaeology; Larry, J., Karen, Z., Vitelli, D., Hollowell-Zimmer, J., Eds.; Altamira Press: Walnut Creek, CA, USA, 2003; pp. 143-152.

46. Moyer, T.S. To Have and Enjoy the Liberty of Conscience. In Places in Mind: Public Archaeology as Applied Anthropology; Shackel, P.A., Chambers, E.J., Eds.; Routledge: London, UK, 2004; pp. 85-100.

47. Cressey, P.J.; Reeder, R.; Bryson, J. Held in Trust: Community Archaeology in Alexandria, Virginia. In Archaeologists and Local Communities: Partners in Exploring the Past; Derry, L., Malloy, M., Eds.; Society for American Archaeology: Washington, DC, USA, 2003; pp. 1-18.

48. Derry, L. Consequences of Involving Archaeology in Contemporary Community Issues. In Archaeologists and Local Communities: Partners in Exploring the Past; Derry, L., Malloy, M., Eds.; Society for American Archaeology: Washington, DC, USA, 2003; pp. 19-29.

49. Smith, C.; Jackson, G. The Ethics of Collaboration: Whose Culture? Whose Intellectual Property? Who Benefits? In Collaboration in Archaeological Practice: Engaging Descendant Communities; Colwell-Chanthaphonh, C., Ferguson, T.J., Eds.; Altamira: Lanham, MD, USA, 2008; pp. 171-199.

50. Ardren, T. Conversations about the production of archaeological knowledge and community museums at Chunchucmil and Kochol, Yucatán, México. World Archaeol. 2002, 34, 379-400. [CrossRef]

51. Chambers, E.J. Epilogue: Archaeology, Heritage and Public Endeavor. In Places in Mind: Public Archaeology as Applied Anthropology; Shackel, P.A., Chambers, E.J., Eds.; Routledge: London, UK, 2004; pp. 193-208.

52. Little, W. Mayas in the Marketplace: Tourism, Globalization and Cultural Identity; University of Texas: Austin, TX, USA, 2004.

53. Torres, R.M.; Momsen, J.D. Gringolandia: The Construction of a New Tourist Space in Mexico. Ann. Assoc. Am. Geogr. 2005, 95, 314-335. [CrossRef]

54. Brown, D.F. Mayas and Tourists in the Maya World. Hum. Organ. 1999, 58, 295-304. [CrossRef]

55. Magnoni, A.; Ardren, T.; Hutson, S.R. Tourism in the Mundo Maya: Inventions and (Mis)Representations of Maya Identities and Heritage. Archaeologies 2007, 3, 353-383. [CrossRef]

56. Moser, S.; Glazier, D.; Phillips, J.E.; El Nemr, L.N.; Mousa, M.S.; Aiesh, R.N.; Richardson, S.; Conner, A.; Seymour, M. Transforming Archaeology through Practice: Strategies for Collaborative Archaeology and the Community Archaeology Project at Quseir, Egypt. World Archaeol. 2002, 34, 220-248. [CrossRef]

57. Rodriguez, T. Maya Perception of Ancestral Remains: Multiple Places in a Local Space. 2001 Berkeley McNair Res. J. 2001, 9, 21-46.

58. Pyburn, K.A. Archaeology for a New Millennium: The Rules of Engagement. In Archaeologists and Local Communities: Partners in Exploring the Past; Derry, L., Malloy, M., Eds.; Society for American Archaeology: Washington, DC, USA, 2003; pp. 167-184.

59. Wylie, A. Why Standpoint Matters. In Science and Other Cultures: Issues in Philosophy of Science and Technology; Figueroa, R., Harding, S., Eds.; Routledge: New York, NY, USA, 2003; pp. 26-48.

60. Wylie, A. The Integrity of Narratives: Deliberative Practice, Pluralism, and Multivoclaity. In Evaluating Multiple Narratives: Beyond Nationalist, Colonialist, Imperial Archaeology; Habu, J., Fawcett, C., Matsunaga, J., Eds.; Springer: New York, NY, USA, 2008; pp. 201-212.

61. Lewin, E.; Leap, W.L. Introduction. In Out in the Field: Selections of Lesbian and Gay Anthropologists; Lewin, E., Leap, W.L., Eds.; University of Illinois Press: Urbana, IL, USA, 1996; pp. 1-28.

62. Krishnan, S. 'Dispatches from a 'rogue' ethnographer: Exploring homophobia and queer visibility. J. Anthr. Soc. Oxf. 2015, 7, 64-79.

63. Valentine, G. The Geography of Women's Fear. R. Geogr. Soc. 1989, 21, 385-390.

64. Wesp, J.K.; Ivone Kú, M.Y.; Haun, M.; Kú Rodriguez, M.E.; Ardren, T.; Moo Kú, M.K. İNos Rebelamos! Negotiating women's work in the midst of power, socio-economic need, and heritage in Yucatan today. In Proceedings of the 10o Congreso Internacional de Mayista, Los Mayas: Discursos e Imágenes del Poder, Izamal, Yucatan, Mexico, 27 June 2016. 
65. Gero, J. Socio-politics and the woman-at home ideology. Am. Ant. 1985, 50, 342-350. [CrossRef]

66. Atalay, S. Indigenous Archaeology as Decolonizing Practice. Am. Ind. Quart. 2016, 30, 280-310. [CrossRef]

67. Colwell-Chanthaphonh, C.; Ferguson, T.J. Collaboration in Archaeological Practice: Engaging Descendant Communities; Altamira: Lanham, MD, USA, 2018.

68. Silliman, S.W. Collaborating at the Trowel's Edge: Teaching and Learning in indigenous Archaeology; University of Arizona Press: Tucson, AZ, USA, 2008.

69. Navarrete, F. Ruins and the State: Archaeology of a Mexican Symbiosis. In Indigenous Peoples and Archaeology in Latin America; Gnecco, G., Ayala, P., Eds.; Left Coast Press: Walnut Creek, CA, USA, 2011.

70. Green, L.; Green, D.; Neves, E.G. Indigenous Knowledge and Archaeological Science: The Challenges of Public Archaeology in the Area Indigena do Uaca. In Indigenous Peoples and Archaeology in Latin America; Gnecco, G., Ayala, P., Eds.; Left Coast Press: Walnut Creek, CA, USA, 2011; pp. 179-200.

71. Overholtzer, L. The Field Crew Symposium: A Model for Initial Implementation of a Collaborative Archaeology Project. Adv. Archaeol. Pract. 2015, 3, 50-62. [CrossRef]

72. Atalay, S. 'We don't talk about Çatalhöyük, we live it': Sustainable archaeological practice through community-based participatory research. World Archaeol. 2010, 42, 418-429. [CrossRef]

73. Pitblado, B. An Argument for Ethical, Proactive, Archaeologist-Artifact Collector Collaboration. Am. Ant. 2014, 79, 385-400. [CrossRef]

74. Davis-Salazar, K.L.; Wells, E.C.; Moreno-Cortés, J. Balancing Archaeological Responsibilities and Community Commitments: A Case from Honduras. J. Field Archaeol. 2007, 32, 196-205. [CrossRef]

75. Stottman, M.J. From the Bottom Up: Transforming Communities with Public ARchaeology. In Transforming Archaeology: Activist Practices and Prospects; Atalay, S., Clauss, L.R., McGuire, R.H., Welch, J.R., Eds.; Left Coast Press: Walnut Creek, CA, USA, 2014; pp. 179-196.

76. Jiménez, C.; Guadalupe, N. ArqueoFest: La historia de la domesticación; Technical Report Submitted to the Consejo Nacional de Ciencia y Tecnología: Mérida, Yucatán, 2019.

(C) 2020 by the authors. Licensee MDPI, Basel, Switzerland. This article is an open access article distributed under the terms and conditions of the Creative Commons Attribution (CC BY) license (http://creativecommons.org/licenses/by/4.0/). 